Firm, Owner, and Financing Characteristics: Differences between Female- and Male-owned Small Businesses

\author{
Alicia Robb* \\ Federal Reserve Board of Governors \\ John Wolken* \\ Federal Reserve Board of Governors
}

March 2002

* The authors would like to thank Rachael Tan for excellent research assistance. Ken Brevoort, Courtney Carter, Robin Prager, Glenn Canner, and David Ribar provided helpful comments. The views expressed in this paper are the views of the authors and do not necessarily reflect the views of the Board of Governors of the Federal Reserve or its staff. All remaining errors are those of the authors. 


\title{
Firm, Owner, and Financing Characteristics: Differences between Female- and Male-owned Small Businesses
}

\author{
Alicia Robb* \\ Federal Reserve Board of Governors \\ John Wolken* \\ Federal Reserve Board of Governors
}

March 2002

\begin{abstract}
Differences in financing patterns and financial characteristics between female- and male-owned firms are often attributed to imperfections in credit markets. However, these differences could arise for many reasons, such as differences in the characteristics and preferences of owners and firms. The differences in lending patterns by gender may in fact have little or nothing to do with supply side factors or market imperfections. The goal of our paper is to test the hypothesis that differences in financing patterns between female- and male-owned small businesses can be explained by differences in business, credit history, and owner characteristics other than gender. In what follows, we first describe how owner, business, and financing characteristics of femaleowned businesses differ from male-owned businesses. We then conduct a multivariate analysis of indicators of credit use and recent lending experiences, modeling each of these as a function of firm, owner, and credit history characteristics.
\end{abstract}




\section{Introduction}

Differences in financing patterns and financial characteristics between female- and maleowned firms are often attributed to imperfections in credit markets (see e.g., Cavalluzzo, Cavalluzzo, and Wolken 2001). However, these differences could arise for many reasons, such as differences in the characteristics and preferences of owners and firms. For example, smaller firms generally require less working capital than larger firms. The size, type, and age of a firm may impact both the need and the ability of a firm to obtain various types of financing. Newer firms may need additional working capital to expand but be less likely to be approved for credit because of their limited performance history. The differences in lending patterns by gender may in fact have little or nothing to do with supply side factors or market imperfections.

The goal of our paper is to test the hypothesis that differences in financing patterns between female- and male-owned small businesses can be explained by differences in business, credit history, and owner characteristics other than gender. In what follows, we first describe how owner, business, and financing characteristics of female-owned businesses differ from male-owned businesses. We then conduct a multivariate analysis of indicators of credit use and recent lending experiences, modeling each of these as a function of firm, owner, and credit history characteristics.

\section{Data Description}

The data for this study were compiled from the 1998 Survey of Small Business Finances (SSBF), a survey conducted by the Federal Reserve Board every five years. The 1998 SSBF collected data for fiscal year 1998 for a nationally representative sample of more than 3,500 forprofit, non-governmental, non-agricultural businesses with fewer than 500 employees. (For more information on the survey, see Bitler, Robb, and Wolken, 2001). In this study, we restrict our analysis to the 2,692 non-Hispanic white-owned businesses that were not equally owned by men and women. ${ }^{1}$ All results reported in this paper were weighted to adjust for sampling design and unequal response rates, and hence are to be interpreted as population estimates.

\footnotetext{
${ }^{1}$ In this study, a firm is defined as female-owned if more than 50 percent of the owners (or ownership shares) are female. Firms were asked if more than 50 percent of the firm was owned by women. Firms that volunteered they were equally owned by men and women (about 3 percent of all non-Hispanic white-owned businesses) were excluded from this sample. Minority and Hispanic-owned businesses are excluded because the sample sizes for female minority-owned firms were too small to analyze separately from men. We also did not want to confound gender effects with possible race effects.
} 
We examined various firm and owner characteristics, credit history, recent borrowing experiences, and the frequency and sources of financial services. A data dictionary is provided in Appendix A, which lists the name and a brief description for each variable. Firm characteristics include: size (employment, sales and assets), industry (manufacturing; mining and construction; wholesale; retail; services; finance, insurance, and real estate; and transportation, communications, and public utilities), organizational form (proprietorship, partnership, C- or Scorporation), firm age, whether the firm is located in a metropolitan statistical area (MSA), and number of offices. Owner characteristics include sex, age, education, and experience. Credit history indicators include the Dun and Bradstreet credit score, bankruptcy, delinquency on personal or business obligations, judgments, and personal home ownership. Recent credit experience variables include whether the firm applied for new credit in the past three years, the disposition of the application, the approved interest rate, points to close, total cost of obtaining the loan, and whether the firm did not apply for new credit for fear the application would be denied. The last set of variables reflect financing patterns of the firm and include dummy variables indicating whether the firm used checking, savings, various types of loans, trade credit, business and personal credit cards, owner loans, as well as if they used credit cards or trade credit for borrowing. ${ }^{2}$ In addition, the type of institution was identified for the firm's selfidentified primary institution.

\section{Descriptive Analysis}

\section{Firm and Owner Characteristics}

Earlier research has found that businesses owned by women tended to be smaller and younger and were more likely to provide retail sales or services (U.S. Census Bureau 2001, Robb 2000, Brush 1990). As shown in Table 1, in 1998 female-owned firms were significantly smaller than male-owned firms when measured by employment, assets, or sales. ${ }^{3,4}$ Female-owned

\footnotetext{
${ }^{2}$ Credit cards and trade credit are used both for financing purposes and for convenience. Firms may use credit cards or trade credit and always pay balances by the next due date. We classify those credit card and trade credit users as convenience users. Firms that carry outstanding balances on their credit cards, or pay after the due date on their trade credit are more apt to the be the firms using these instruments as a form of credit than are those firms paying off credit card balances and trade credit balances each month. Since we are interested in financing patterns, we considered a firm to have used credit cards for financing only if firms carried balances and to have used trade credit for financing only if firms paid after the due date.

${ }^{3}$ Because size is highly correlated with many firm characteristics (including financing patterns) as well as female ownership, observed univariate differences in characteristics might be the result of spurious correlation with male/female ownership. To analyze this possibility, and to help control for this sample property, we considered
} 
businesses were more likely to be in retail trade or services, and less likely to be in construction, mining, and wholesale trade than were male-owned businesses. Female-owned businesses were more likely to be organized as sole proprietorships, less likely to be incorporated (as either an Sor C-corporation), and about as likely to be organized as partnerships as were male-owned businesses. Female-owned firms were significantly younger than male-owned firms, with female-owned firms averaging 11 years compared with male firms averaging 15 years. Lastly, female-owned firms had significantly smaller (absolute) profits than did male-owned businesses.

Evidence suggests that characteristics attributed to "successful" entrepreneurs are more commonly ascribed to men than to women (Buttner and Rosen 1988) and that human capital plays an important role in the growth and survival of a business (Lucas 1978, Jovanovic 1982, Robb 2000). The success of a business will depend on the owner's ability to obtain the necessary financial capital, which may be obtained from banks, venture capitalists, or other sources (Adrich and Zimmer 1985). This ability is often a function of the perceived human capital of the firm. Since human capital is difficult to measure, owner education, experience, and age are all often used as proxies. In this analysis, we use the dummy variable "college" to indicate that the owner has at least a college degree. Experience is designated as the total number of years the owner has spent operating a business (including the current business). Male owners had higher levels of both education and experience on average than did women, and these differences were both statistically significant (see Table 1). Male owners were also slightly older than female owners. Hence, there is some evidence that the levels of human capital of female-owned firms were lower than those of male-owned firms.

\section{Financing Patterns, Credit History and Institution Use}

We next turn to an examination of the differences in financing patterns between femaleand male-owned businesses. We examined whether firms had outstanding loans, as well as

\footnotetext{
various subcategories of the firms in our univariate analysis. The first group was restricted to firms below the $95^{\text {th }}$ percentile of female-owned firm sales, while the second group is restricted to firms with fewer than 5 employees. The third group consisted of firms that are five years old or younger. Because nearly half of female-owned businesses were in the service industry, descriptive statistics were also examined separately for these firms (group four). The univariate differences for firm and owner characteristics were still significant for these subgroups, as were differences in credit history, financing patterns, and recent borrowing experiences. These results are presented in Appendix B.

${ }^{4}$ Population means are estimated using survey weights. The t-tests use robust standard errors that account for unequal weighting and sample stratification.
} 
whether the businesses obtained credit via credit cards or trade credit. A firm was said to have an outstanding loan if it had one or more of the following: credit lines, mortgages used for business purposes, motor vehicle loans, equipment loans, other loans, or capital leases. As shown in Table 2, the proportion of female-owned businesses that had an outstanding loan was smaller than the proportion of male-owned businesses, and the difference was statistically significant. Most of the specific loan types (capital leases, credit lines, equipment loans, and motor vehicle loans) were used less often by female-owned businesses than male-owned businesses. The differences between female- and male-owned businesses for these loan types were all statistically significant. These results are consistent with previous studies (Chaganti 1986, Collerett and Aubrey 1990, Carter and Cannen 1992, Boden and Nucci 2001). Mortgages and "other" loans were used by about the same proportion of female- and male-owned businesses.

In addition to obtaining credit using lines of credit and other loans, businesses might also borrow using credit cards or trade credit. Female-owned firms reported using business credit cards somewhat less and personal credit cards about the same as male-owned businesses. Despite this finding, women-owned businesses were significantly more likely to borrow using credit cards (carried an outstanding balance on personal or business credit cards following regular monthly payments) than were male-owned businesses. Female-owned businesses used trade credit and borrowed using trade credit (paying after the due date) less frequently than maleowned firms. These differences were both statistically significant.

Longer term relationships with a commercial bank or other financial institution may indicate that a firm has a "formal" relationship in financial markets, which some (Rajan and Petersen 1994, Berger and Udell 1995) have argued is important to gaining access to credit markets. Previous research indicates that firms owned by women are less likely to use commercial banks for their financial services (Haynes 1999, Cole and Wolken 1995, Scherr et al 1993). Table 2 includes variables measuring whether the firm used any financial services, whether the firm's primary institution was a commercial bank, and the length of relationship with the firm's primary institution. Female-owned firms were significantly less likely to have at least one financial service from sources other than the firm's owners. Although the proportion of female-owned businesses was smaller than the proportion of male-owned businesses having a bank as their primary institution, the difference in proportions was not statistically significant. 
Lastly, female-owned businesses had significantly shorter relationships with their primary institutions than male-owned businesses. This latter finding may be due to the fact that femaleowned firms are typically younger than male-owned firms.

A firm's credit history is an important determinant of whether a firm can obtain credit. Since owner and firm finances are often commingled and somewhat indistinguishable for some smaller businesses, the credit history of the owner may be just as important as the credit history of the firm. The bottom portion of Table 2 presents means of variables related to the firm's credit history and recent borrowing experiences. As measured by Dun and Bradstreet's credit score, firms owned by women were considered to be higher risk than firms owned by men. ${ }^{5}$ This difference was statistically significant. There appears to be very little difference in the individual mean estimates between female- and male-owned businesses for the self-reported credit history variables (bankruptcy, delinquency on personal or business obligations, judgments against firm or owner, denied trade credit, and home ownership), and none of the differences were statistically significant.

\section{Recent Borrowing Experiences}

The recent borrowing experiences of female and male business owners are shown in the bottom portion of Table 2. Businesses owned by women were significantly less likely to have applied for a new loan in the last three years. This is consistent with the fact that women-owned firms were less apt to have outstanding credit and may simply reflect a difference in credit demand. However, there is some evidence that differences in application rates could in part be the result of certain firms selecting to not apply because they thought they might be turned down. ${ }^{6}$ The proportion of female-owned firms fearing denial was greater than the proportion of male-owned firms for all groups of firms, and the difference was statistically significant at the 90 percent confidence level.

Despite difference in loan application rates, however, approval rates for female- and male-owned firms that did apply for new credit were not statistically different. In addition, there were no significant differences in loan terms, including interest rates, points paid to close the loan, and the total cost of obtaining the loan once the loans were approved.

\footnotetext{
${ }^{5}$ Larger values of the Dun and Bradstreet credit score imply lower risk or greater creditworthiness.

${ }^{6}$ Surveyed firms were asked if there were times in the last three years when the firm required credit but did not apply because it thought it would be turned down. Firms that indicated they had feared denial were then asked why.
} 


\section{Multivariate analysis}

All of the results reported thus far have used univariate comparisons. From these results, we found differences in the firm and owner characteristics of female- and male-owned firms, as well as differences in their use of credit. We now estimate whether there were differences between female- and male-owned firms' credit use, after controlling for many of the differences in firm, owner, and credit history characteristics. We examine five dependent variables related to credit use: 1) firm had outstanding loans; 2) firm borrowed using trade credit; 3) firm borrowed using credit cards; 4) firm applied for credit in last three years; and 5) firm did not apply for credit for fear the application would be denied. For each of these variables, there were significant univariate differences between female- and male-owned firms. We estimate a reduced-form multivariate logistic equation of the following form for each of the dependent variables ${ }^{7}$ :

$$
\begin{gathered}
Y=\alpha+\beta(\text { female })+\delta(\text { firm characteristics })+\gamma(\text { owner characteristics })+ \\
\eta(\text { credit history })+\phi(\text { financing characteristics })+\varepsilon
\end{gathered}
$$

Female is a dummy variable indicating the firm was female-owned. If differences in credit use patterns can be explained by firm and owner characteristics (other than sex), then the coefficient on female $(\beta)$ should not be significantly different from zero. ${ }^{8}$

Dependent variables: The first three dependent variables focus on different credit products - loans, credit cards, and trade credit. These types of credit could be substitutes (generally credit obtained from credit cards and trade credit are likely to be more expensive than other loans, are usually extended for short periods of time, and in the case of trade credit, are extended only in conjunction with the use of other services). Alternatively, the different types of credit may be complimentary. As credit demand increases for a firm, it may increase for all

\footnotetext{
${ }^{7}$ Robustness checks included interacting female with specific variables of interest such as industry and size as well as running regressions separately by industry. Generally, female was not significant in most interactions and most subpopulations. The exceptions are: for interactions-in the trade credit equation female interacted with all industries and female interacted with retail; for the credit card equation female interacted with all industries; and for loan application, female interacted with all size measures. In the separate industry equations--in the loan equation, female was positive and significant in FIRE and negative and significant in services; in the trade credit equation female was positive and statistically significant in retail and FIRE; in the credit card borrowing equation, female was negative and significant in TCPU and positive and significant in retail and manufacturing; in the loan application equation, female was positive and significant in TCPU and negative and significant in services; and in the feared equation, female was positive and significant in mining and construction.

${ }^{8}$ The tests for differences of means mentioned previously are equivalent to running the model $Y=\alpha+\beta$ (female) + $\varepsilon$ and testing whether the coefficient $\beta$ is significantly different from zero.
} 
types of credit. The final two dependent variables, applied for new credit and feared applying, focus on recent borrowing experiences.

Independent variables:

Firm Characteristics

\begin{tabular}{|l|l|}
\hline Size & $\begin{array}{l}\text { Log of employment, Log of sales, Log of assets, and Log of number } \\
\text { of offices }\end{array}$ \\
\hline Industry & $\begin{array}{l}\text { Manufacturing; Mining and Construction; Wholesale; Retail; } \\
\text { Finance, insurance, and real estate (FIRE); Transportation, } \\
\text { communications, and public utilities (TCPU); and Services and } \\
\text { other }\end{array}$ \\
\hline Organizational form & Sole proprietorship, Partnership, C corporation, and S corporation \\
\hline Location & MSA and non-MSA (metropolitan statistical area) \\
\hline Firm Age & $\begin{array}{l}\text { Very young (1-3 years), Young (4-9 years), Middle (10-19 years), } \\
\text { and Old (20+ years) }\end{array}$ \\
\hline
\end{tabular}

Size is likely to be positively related to the demand for credit and as such is a crude proxy for credit demand. Organizational form affects the assignment of liability and thus could affect the optimal levels of debt (vis-à-vis equity). Organizational form also affects the ability of creditors to collect on delinquent loans, and hence the supply of credit to firms. Firms in different industries have different requirements for credit - including trade credit. For example, firms in service industries have lower demands for trade credit than do firms in manufacturing and wholesale, where typically inventories of goods, services, and supplies are maintained. Firm age may also affect whether firms use credit, both from a demand and a supply side. On the demand side, new firms and expanding firms are likely to have higher credit demands than older, well-established businesses. However, on the supply side, firms with few years of experience may find it difficult to secure credit from banks and other institutional creditors since the firms have a limited performance history.

Owner characteristics

\begin{tabular}{|l|l|}
\hline Sex & Female, Male \\
\hline Education & College Degree,+ less than college degree \\
\hline Age & $\begin{array}{l}\text { Very young (less than 35 years old), young (35-45 years), middle (46-55 } \\
\text { years), and older (56+ years) }\end{array}$ \\
\hline Experience & $\begin{array}{l}\text { Low (less than five years), medium (5-9 years), high (10-19 years), and very } \\
\text { high (20+ years) }\end{array}$ \\
\hline
\end{tabular}


Each of these variables is a proxy for human capital and thus should be positively related to credit worthiness and the supply of credit.

\section{Credit history}

\begin{tabular}{|l|l|}
\hline Dun \& Bradstreet Credit Score & $\begin{array}{l}\text { 1-100\%, higher number indicating greater } \\
\text { creditworthiness }\end{array}$ \\
\hline Bankruptcy & $\begin{array}{l}1 \text { if personal or business bankruptcy in the } \\
\text { last seven years, else 0 }\end{array}$ \\
\hline Delinquency on personal obligations & $\begin{array}{l}1 \text { if three or more delinquencies of } 60 \text { days } \\
\text { or more on personal obligations, else } 0\end{array}$ \\
\hline Delinquency on business obligations & $\begin{array}{l}1 \text { if three or more delinquencies of } 60 \text { days } \\
\text { or more on business obligations, else } 0\end{array}$ \\
\hline Judgements & $\begin{array}{l}1 \text { if any judgements against business or } \\
\text { owner, else } 0\end{array}$ \\
\hline Denied trade credit & $\begin{array}{l}1 \text { if business had ever been denied trade } \\
\text { credit, else } 0\end{array}$ \\
\hline Home ownership & 1 if principal owner owns home, else 0 \\
\hline
\end{tabular}

Credit history variables include the Dun and Bradstreet credit score for the firm, which is an independent assessment of the creditworthiness of the firm. Additionally, self-reported credit history variables include indicators for personal or business bankruptcy in past seven years, more than three delinquencies on personal obligations, more than three delinquencies on business obligations, and judgments against the owner. Also related to credit history are whether the firm has recently been denied trade credit, and whether the business owner owns his or her home. From the supply side, all of these variables except home ownership should be negatively related to credit use. Anticipating the effect from the demand side is more complicated. On the one hand, knowledge of one's credit history may reduce expectations of being able to obtain credit and could reduce a firm's demand. Having a poor credit history may also increase the fear that one's loan application would be denied. Also, if trade credit and credit card debt are inferior substitutes for ordinary credit, low credit history may increase the propensity for these types of credit and decrease the propensity for loans. Yet, in order to be delinquent on a business or personal obligation, it is necessary that some credit be extended in the first place. Thus, in this reduced form context, some of these variables might be positively associated with credit demand and the analysis variables. Hence, a priori it is difficult to predict the sign of the credit history variables' coefficients. 
Financing characteristics

\begin{tabular}{|l|l|}
\hline Checking & 1 if firm has a checking account, else 0 \\
\hline Savings & 1 if firm has a savings account, else 0 \\
\hline Owner loan & 1 if firm has an owner loan, else 0 \\
\hline Trade Credit Borrowing & 1 if firm borrows using trade credit, else 0 \\
\hline Credit Card Borrowing & 1 if firm borrows using credit card, else 0 \\
\hline
\end{tabular}

These characteristics vary from model to model and include indicators for the types of financial services used by the firm (checking, savings, owner loans, regular loans, trade credit, credit cards). Having loans, borrowing using trade credit, and borrowing using credit cards could be substitutes for credit. Indeed, some have argued that borrowing using trade credit or credit cards is actually an indicator of credit constraints, since it is presumed that trade credit and credit cards are more expensive sources of credit. However, because we examined these factors in a reduced-form setting, it is possible that each of these were also proxies for credit demand - firms that used loans also used credit cards and trade credit for borrowing. ${ }^{9}$

\section{Multivariate results:}

Outstanding loans: The dependent variable in the first logistic model is whether the firm has any outstanding credit lines, capital leases, mortgages, motor vehicle or equipment loans, or any "other" loans (such as unsecured term loans), shown in column 1 of Table 3. Firm characteristics that were statistically significant include age, size (all three measures), industry, organizational form (C corporation), and MSA. Larger firms and firms between four and nine years of age were more likely than smaller and older firms to have an outstanding loan. Firms in mining, construction, finance, insurance, and real estate were more likely to have an outstanding loan than firms in manufacturing. Finally, firms located in MSAs were less apt to have outstanding loans.

Of the credit history variables, bankruptcy and delinquent on business obligations were significantly different from zero. Firms that filed for bankruptcy in the past seven years were less apt to have outstanding loans but firms that have been delinquent on business obligations were more likely to have outstanding loans.

\footnotetext{
${ }^{9}$ In future work, we will model the three dimensions of credit use (loans, credit card borrowing, and trade credit borrowing) in a simultaneous equations framework. In the descriptive regressions reported below, these three variables are included as right-hand-side variables only in the application and fear equations.
} 
Only owner age was statistically significant among the owner characteristics with owners between 35-45 years old and 46-55 years old being more likely to have loans than firms owned by older individuals. Owner education and experience were not statistically significant. This seems to indicate firm factors were more important in determining whether or not a firm has an outstanding loan. We reported earlier that 58 percent of male-owned businesses and 47 percent of women-owned businesses had outstanding loans and that this difference was statistically significant. After accounting for various firm and owner characteristics, however, the coefficient on female is negative, but not significantly different from zero. Hence, whether firms have outstanding loans appears to be a function of characteristics of the firm and owner other than the sex of the owners.

Trade credit borrowing: In this model, the dependent variable is the indicator of whether the firm repaid trade credit after the due date (borrowed). As shown in column 2 of Table 3, the coefficients of both the log of sales and $\log$ of assets were positive and significant, indicating that larger firms were more likely to borrow on trade credit. The same held true for $\mathrm{C}$ corporations. Industry was significant as well, with firms in retail; transportation, communications and public utilities; and finance, insurance and real estate less likely than manufacturing firms to use trade credit borrowing.

The coefficients on all of the credit history variables, except judgments, were statistically significant. The Dun and Bradstreet credit score is negative indicating that the more creditworthy a firm, the less likely it is to borrow using trade credit. This finding is consistent with the view that riskier firms have to use trade credit as a source of financing, since it is believed that trade credit is a more expensive source of credit. Delinquencies on both personal and business obligations were positive, which is not too surprising given that the dependent variable is defined as paying trade credit obligations after their due date (i.e., being delinquent).

Owners with less experience were less likely to borrow through trade credit, while owners between the ages of 35 and 55 were more likely to borrow using trade credit. The coefficient on education was negative, indicating more educated owners were less likely to borrow using trade credit, but it was not statistically significant. Finally, the coefficient on female was not significant. Although the descriptive statistics indicate that women-owned firms were less likely to borrow using trade credit, we conclude that differences in trade credit 
borrowing between men- and women-owned businesses can be explained by characteristics other than the sex of the owners.

Credit card borrowing: The dependent variable in this model is an indicator of whether the firm borrowed using business or personal credit cards. This variable equals one if the firm used business or personal credit cards and carried balances after monthly payments were made. The univariate means test revealed that a significantly larger proportion of female-owned businesses borrowed using credit cards compared with male-owned businesses. Results for this equation, shown in column 3 of Table 3, differ somewhat from earlier equations. The youngest firms were more likely to borrow using credit cards than were the older firms. Size was not significant. Incorporated businesses ( $\mathrm{S}$ and $\mathrm{C}$ corporations) were less likely than sole proprietorships to borrow through credit card use. Overall, industry was significant and firms in mining, construction, and finance, insurance, and real estate were less likely than firms in manufacturing to borrow through the use of credit cards.

As shown by the estimates for the coefficients on the credit history variables, less creditworthy firms use credit card borrowing more often than more creditworthy firms. The coefficient on the D\&B credit score is negative, indicating that firms with higher credit scores (less risky) were less likely to use credit card borrowing. The coefficients on personal and business delinquencies were positive and significant indicating that firms using credit card borrowing had poorer credit histories. Firms that had owner loans were also more likely to have credit card borrowing.

While the results indicated that firms with the least experienced owners were less likely to use credit card borrowing, the other owner characteristics were not statistically significant. Yet, the coefficient on female was both positive and statistically significant, indicating that after the firm and owner characteristics were accounted for, women were more likely than men to use credit cards for borrowing.

\section{Recent Borrowing Experiences:}

We next estimate logistic equations for indicators of the firm's recent borrowing experiences: 1) did a firm apply for credit in the last three years and 2) did a firm not apply for credit because it "feared" it would be denied. The models for these variables include the same 
basic set of explanatory variables (firm characteristics, owner characteristics, credit history), as well as indicators of whether the firm uses loans, credit card credit, and trade credit borrowing.

Our descriptive analysis suggested that a significantly smaller percentage (19 percent) of female-owned businesses attempted to borrow than did male-owned businesses (24 percent). Yet of those firms applying, the acceptance rates were about equal for female- and male-owned businesses (76 percent). Generally, a larger proportion of female-owned businesses did not apply for fear of denial, and the difference between female- and male-owned businesses was statistically significant at the 90 percent confidence level.

Applied for Loan: Firm characteristics significantly influencing loan application include firm age, size (employment, sales, assets, number of offices), and headquarters located in an MSA. (Results are in column 4 of Table 3). Younger firms were more likely to apply than older firms, while larger firms were more likely to apply than smaller firms. Firms were more apt to apply if they had been delinquent on personal obligations, had a judgement against them, or had been denied trade credit. Finally, younger owners (ages 35-45) were more likely to apply for loans than older owners.

After accounting for differences in firm and owner characteristics, the coefficient on female was negative, but not statistically significant. Differences between female- and maleowned business application rates appear to be explained by firm and owner characteristics other than the sex of the owners. A model on loan approval (not shown here) indicated that after accounting for credit history and firm characteristics, there were no significant differences in loan approvals between female- and male-owned businesses.

Did not apply for fear of being denied: Younger firms (4-9 years old) were more likely than older firms to not apply for loans for fear of denial (column 5 of Table 3). Size did not appear to matter. All of the credit history variables were statistically significant and generally indicated that firms with poor credit histories were more likely to fear denial. Home ownership was significant and negatively related to fear of denial. Those firms that had owner loans or had borrowed using loans or credit cards were more likely to have not applied for fear of denial. Younger owners (ages 35-55) were also more likely than owners 56 years or older, to have not applied for fear of denial.

The coefficient on female was not significant, indicating that the sex of the owners was not a factor in this decision. Indeed, there was very little difference in the reasons given by men 
and women for fearing loan application denial. For both men and women, a little more than half mentioned their credit quality as a factor, while about a third said they feared that the perception of the prospective institution was a factor. Although a greater proportion of women cited discrimination, only three and a half percent of women said this was a factor that caused them not to apply for a loan.

Thus, it appears that fear of denial is significantly related to owner characteristics and credit history. The types of credit used by the firm also play a role. In general, riskier firms were more likely to not apply for a loan because of fear they would be turned down. After accounting for owner and credit history effects, there were no significant differences between female- and male-owned businesses' fear of denial.

\section{Conclusion}

The univariate analysis of female- and male-owned businesses revealed several significant differences in firm and owner characteristics, credit histories, and credit experiences of small businesses. Female owned firms were smaller, younger, more concentrated in retail sales and services, and more likely to be organized as proprietorships than were male-owned firms. Female- and male-owned businesses had similar self-reported credit histories, but femaleowned businesses were considered to be greater credit risks than were male-owned firms as measured by the Dun and Bradstreet credit score. Although female-owned firms were less likely to have applied for new credit than were male-owned firms, once they applied there were no significant differences between female- and male-owned firms in the approval rates or loan terms. Finally, we found that female-owned firms were less likely to have outstanding loans, less likely to use business credit cards and trade credit, less likely to borrow using trade credit, and more likely to borrow with credit cards than were male-owned firms.

In the multivariate analysis we generally found that credit use by female- and maleowned businesses differed primarily due to characteristics other than the sex of the owners, credit card borrowing being the exception. We also found evidence that credit card and trade credit borrowing were generally associated with less creditworthy firms and owners, which is consistent with the view that credit card and trade credit are more expensive and hence imperfect substitutes for loans. The differences in loans held by firms appear to be driven by demand rather than supply. Indeed, the approval rates from the univariate results indicate that there was 
no significant difference between female- and male-owned businesses. While more women indicated that they did not apply for fear of denial, the multivariate analysis indicated that the main reasons behind this fear for both men and women were related to credit history. Indeed, in a follow up question, respondent that feared denial generally indicated financial reasons. Only a small proportion of survey respondents-male or female-indicated that discrimination was a reason for fearing denial.

Our results indicate that there are systematic sex differences in firm and owner characteristics that give rise to many of the observed differences in lending patterns by gender. However, we cannot address the fundamental issue that disparities exist in the factors that men and women bring to their business ventures (such as education and experience). Nor can we address the vast differences in industrial or size choices that men and women make when forming their ventures. ${ }^{10}$ The pre-market forces in effect may be different for women than for men but cannot be evaluated here. However, our results do indicate that, in general, the differences by sex in lending patterns for these existing businesses did not appear to result from credit market imperfections.

\footnotetext{
${ }^{10}$ The reasons for entering into a business could have profound effects on the resulting size, industry, and survival of a business. Previous research indicates that women were more likely than men to enter into business for flexibility, family reasons, and for a second income; female-owned businesses were also more likely than male-owned businesses to be part-time ventures (Robb 2000).
} 


\section{References}

Ang, James S., James Wuh Lin, and Floyd Tyler, AEvidence on the Lack of Separation Between Business and Personal Risks Among Small Businesses, @ournal of Small Business_Finance 4 (1995), pp. 197-210.

Aldrich, H. Networking Among Women Entrepreneurs in O. Hagan, C. Rivchun \& D. Sexton (Eds.), Women Owned Businesses. New York: Praeger, 1989.

Berger, Allen N., and Gregory E. Udell, ARelationship Lending and Lines of Credit in Small Firm Finance,@ournal of Business 68(3) (1995), pp. 351-381.

Bitler, Marianne P., Robb, Alicia M. and John D. Wolken, "Financial Services used by Small Businesses: Evidence from the 1998 Survey of Small Business Finances," Federal Reserve Bulletin, April 2001, pp. 183-205.

Blackwell, David W., and Drew B. Winters, ABanking Relationships and the Effect of Monitoring on Loan Pricing, @ournal of Financial Research XX(2) (Summer 1997), pp. 275-289.

Blanchflower, D., P. Levine, and D. Zimmerman. 1998. "Discrimination in the Small Business Credit Market," Working paper, NBER.

Boden, Richard J., Jr., AGender and Self-Employment Selection: An Empirical Assessment, Journal of Socio-Economics 25(6) (1996), pp. 671-682.

, AGender Inequality in Wage Earnings and Female Self-Employment Selection, @ournal of Socio-Economics 28 (1999), pp. 351-364.

, and Alfred R. Nucci, An the Survival Prospects of Men $₹$ and Women New Business Ventures, @ournal of Business Venturing (forthcoming).

Brush, C. 1992. "Research on Women Business Owners: Past Trends, a New Perspective, and Future Directions." Entrepreneurship Theory and Practice 16(4), 5-30.

Brush, C. 1990. "Women and Enterprise Creation: Barriers and Opportunities," in S. Gould and J. Parzen (Eds.), Enterprising Women: Local Initiatives for Job Creation, Paris: OECD, pp. 37-58.

Carsky, Mary, and Susan Coleman, ASources of Capital for Small Family-Owned Businesses: Evidence from the National Survey of Small Business Finances,@ Family Business Review 12(1) (March 1999), pp. 73-85. 
Carter, Nancy M., Mary Williams, and Paul D. Reynolds, ADiscontinuance Among New Firms in Retail: The Influence of Initial Resources, Strategy, and Gender,@ Journal of Business Venturing 12 (1997), pp. 125-145.

Cavalluzzo, Ken, Linda Cavalluzzo, and John D. Wolken, ACompetition, Small Business Financing, and Discrimination: Evidence from a New Survey, @Finance and Economics Discussion Series 1999-25, Board of Governors of the Federal Reserve System (1999)

Chaganti, Radha, AManagement in Women Owned Enterprises,@ournal of Small Business Management (October 1986), pp. 18-29.

Coleman, Susan, ASources of Small Business Capital: A Comparison of Men and Women-Owned Small Businesses, @ournal of Applied Management and Entrepreneurship 4(2) (January 1999), pp. 138-151.

AAccess to Capital and Terms of Credit: A Comparison of Men- and WomenOwned Small Businesses, Journal of Small Business Management 38(3) (July 2000).

Cole, Rebel A., and John D. Wolken, AFinancial Services Used by Small Businesses: Evidence from the 1993 National Survey of Small Business Finances, @f ederal Reserve Bulletin 81 (July 1995), pp. 629-667.

Collerett P. and Aubry, P., ASocio-Economic Evolution of Women Business Owners in Quebec,@Journal of Business Ethics 9 (1990), pp. 417-422.

Cooper, Arnold C., Carolyn Y. Woo, and William C. Dunkelberg, AEntrepreneurship and the Initial Size of Firms, @ournal of Business Venturing 4 (1989), pp. 317-332.

Devine, T. 1994. "Characteristics of Self-employed Women in the United States," Monthly Labor Review, 117: 20-34.

Ennew, Christine T., and Martin R. Binks, AThe Provision of Finance to Small Businesses: Does the Banking Relationship Constrain Performance?,@ournal of Small Business Finance 4 (1994), pp. 57-74.

Evans, David S., and Boyan Jovanovic, AAn Estimated Model of Entrepreneurial Choice under Liquidity Constraints, @ournal of Political Economy 97(4) (1989), pp. 808827. , and Linda S. Leighton, ASome Empirical Aspects of Entrepreneurship, @ire American Economic Review 79(3) (June 1989), pp. 519-535.

Fabowale, Lola, Orser, Barbara, and Riding, Allan, AGender, Structural Factors and Credit Terms Between Canadian Small Businesses and Financial Institutions, @ Entrepreneurship Theory and Practice 19(4) (1995), pp. 41-65. 
Haynes, George W., 1999, AExecutive Summary on Financial Structure of WomenOwned Businesses,@mimeo, Small Business Administration, Office of Advocacy.

Neider, Linda, Areliminary Investigation of Female Entrepreneurs in Florida,@ournal of Small Business Management (July 1987), pp. 22-29.

Petersen, Mitchell A., and Raghuram G. Rajan, AThe Benefits of Lending Relationships: Evidence from Small Business Data,@ournal of Finance 49 (March 1994), pp. 3-37.

Riding, Allan L., and Catherine S. Swift, AWomen Business Owners and Terms of Credit: Some Empirical Findings of the Canadian Experience, @ournal of Business Venturing 5 (1990), pp. 327-340.

Robb, Alicia, 2000, "The Role of Race, Gender, and Discrimination in Business Survival." Doctoral Dissertation, University of North Carolina at Chapel Hill, Chapel Hill, North Carolina.

Scherr, Frederick C., Timothy F. Sugrue, and Janice B. Ward, AFinancing the Small Firm Start-Up: Determinants of Debt Use,@ournal of Small Business Finance 3(1) (1993).

Sexton, D. 1989. "Research on Women-Owned Businesses: Current Status and Future Directions," in O. Hagen, C. Rivchun, and D. Sexton (eds.), Women-Owned Businesses, New York: Praeger, pp. 183-193.

U.S. Bureau of the Census. 1997. 1992 Characteristics of Business Owners. Washington, D.C.: Government Printing Office.

U.S. Bureau of the Census. 2001. 1997 Economic Census, Women-Owned Businesses. Washington, D.C.: Government Printing Office. 
TABLE 1: Means of Firm and Owner Characteristics

\begin{tabular}{|c|c|c|c|c|}
\hline FIRM SIZE & All & $\begin{array}{r}\text { All } \\
\text { Female }\end{array}$ & & $\begin{array}{l}\text { All } \\
\text { Male }\end{array}$ \\
\hline Total Employment (number) & 8.98 & 6.25 & $\star \star$ & 9.88 \\
\hline Assets (in thousands) & 454.24 & 241.81 & $\star \star$ & 524.45 \\
\hline Sales (in thousands) & 1076.69 & 585.14 & $\star \star$ & 1239.14 \\
\hline Number of Sites & 1.40 & 1.12 & & 1.49 \\
\hline \multicolumn{5}{|l|}{ INDUSTRY (percentages) } \\
\hline $\begin{array}{l}\text { Mining, Construction } \\
\text { Manufacturing }\end{array}$ & $\begin{array}{r}12.69 \\
8.68\end{array}$ & $\begin{array}{l}5.79 \\
7.74\end{array}$ & $\star \star$ & $\begin{array}{r}14.97 \\
8.99\end{array}$ \\
\hline $\begin{array}{l}\text { Transportation, Communications, Public } \\
\text { Utilities }\end{array}$ & 3.72 & 3.59 & & 3.76 \\
\hline Wholesale & 7.28 & 3.69 & $\star \star$ & 8.46 \\
\hline Retail & 18.10 & 23.29 & $\star \star$ & 16.39 \\
\hline Finance, Insurance, Real Estate & 6.79 & 5.97 & & 7.06 \\
\hline Services, Other & 42.75 & 49.94 & $\star \star$ & 40.37 \\
\hline \multicolumn{5}{|l|}{ ORGANIZATIONAL FORM (percentages) } \\
\hline C-corporation & 19.96 & 16.97 & $\star \star$ & 20.94 \\
\hline S-corporation & 23.46 & 19.95 & $\star \star$ & 24.62 \\
\hline Partnership & 6.26 & 6.15 & & 6.30 \\
\hline Sole Proprietor & 50.32 & 56.93 & $\star \star$ & 48.14 \\
\hline \multicolumn{5}{|l|}{ OTHER FIRM CHARACTERISTICS } \\
\hline Firm Age (in years) & 13.86 & 11.44 & $\star \star$ & 14.66 \\
\hline Profit (in thousands) & 139.41 & 87.33 & $\star \star$ & 156.63 \\
\hline In a Metropolitan Statistical Area (\%) & 78.20 & 79.47 & & 77.79 \\
\hline \multicolumn{5}{|l|}{ OWNER CHARACTERISTICS (percentages) } \\
\hline College Grad & 48.52 & 42.59 & $\star \star$ & 50.48 \\
\hline Years of Experience & 18.75 & 15.03 & $\star \star$ & 19.98 \\
\hline Age (in years) & 50.54 & 49.27 & $\star \star$ & 50.96 \\
\hline $\mathrm{N}$ & 2692 & 605 & & 2087 \\
\hline
\end{tabular}

* Differences of means significantly different from zero at the 90th percentile.

** Differences of means significantly different from zero at the 95th percentile. 
TABLE 2: Means of Financial Service Use, Institution Use, Credit History, and Recent Borrowing Experiences

USE OF FINANCIAL SERVICES (percentages)

Have Outstanding Loan
Capital Lease
Credit Line
Equipment Loan
Mortgage
Motor Vehicle Loan
Other Loan
Used Business Credit Card
Used Personal Credit Card for Business Purposes
Borrowed on Credit Card
Used Trade Credit
Borrowed on Trade Credit
Checking Account
Savings Account
Loan from Owner(s)
INSTITUTION USE
------------
Used any Institution
Primary Institution is a Bank
Length of Relationship with Primary Institution
in Months

All

55.40

10.66

28.60

10.18

13.04

20.86

9.73

34.61

46.30

15.22

63.22

27.01

94.34

22.98

14.04

96.68

84.24

97.33
All

Female

46.50

7.73

18.78

5.32

13.12

13.33

9.92

29.95

47.36

19.97

53.59

24.12

90.51

24.55

13.42
All

Male

** 58.34

** 11.62

$\star \star \quad 31.84$

** 11.78

13.01

* $\quad 23.35$

9.67

* $\quad 36.15$

45.96

* 13.64

* 66.41

* 27.97

* $\quad 95.60$

22.46

14.25

92.69

82.15

98.00

84.90

$88.32 \star \star 100.15$

\section{CREDIT HISTORY}

Dun \& Bradstreet Credit Score ${ }^{2}$

Denied Trade Credit

Bankruptcy by Firm in Last 7 Years

Delinquency on Personal Obligations

Delinquency on Business Obligations

Judgment Against Owner

Owner Owns Home

51.66

5.05

2.08

6.54

7.83

3.37

89.11

RECENT BORROWING EXPERIENCE

Loan Application

22.87

Multiple Loan Applications

Didn't Apply Fearing Denial

Loan Application(s) Always Approved

Approved Original Interest Rate

Approved Points to Close

Approved Total Cost of Obtaining Loan

$\mathrm{N}$
12.06

21.16

76.21

9.22

0.17

1.61

2692

\begin{tabular}{|c|c|c|}
\hline 48.70 & $\star \star$ & 52.64 \\
\hline 5.51 & & 4.85 \\
\hline 2.03 & & 2.05 \\
\hline 6.50 & & 6.5 \\
\hline 7.06 & & 8.0 \\
\hline 2.77 & & 3. \\
\hline 88.11 & & 89. \\
\hline
\end{tabular}

$\begin{array}{rrr}19.22 & \text { ** } & \mathbf{2 4 . 0 7} \\ 8.12 & \text { * } & 13.37 \\ \mathbf{2 4 . 1 9} & \text { * } & \mathbf{2 0 . 1 6} \\ 76.55 & & 76.11 \\ 8.94 & & 9.29 \\ 0.16 & & 0.17 \\ 1.49 & & 1.64 \\ 605 & & \\ & & 2087\end{array}$

${ }^{1}$ Bold indicates multivariate analysis.

${ }^{2}$ A higher score indicates greater credit worthiness or lower risk

* Differences of means significantly different from zero at the 90th percentile.

**Differences of means significantly different from zero at the 95 th percentile. 
Table 3: Survey Logistic Regression Results

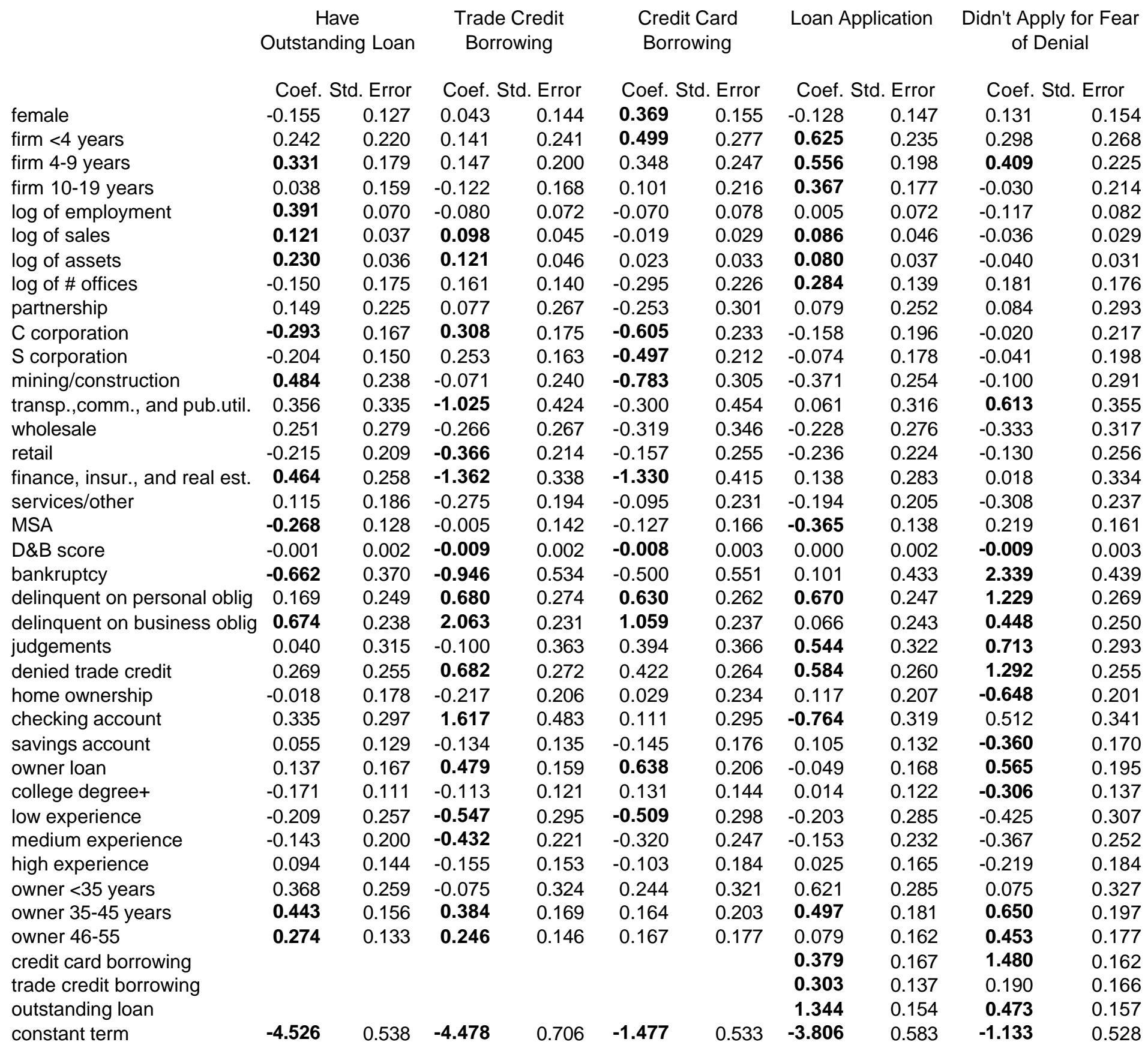

$\mathrm{n}=2692$

Bold indicates statistically significant at $90 \%$ confidence level or more 


\begin{tabular}{|c|c|c|}
\hline Variable & Mean & Description \\
\hline totemp & 8.98 & Business' total number of employees \\
\hline $\mathrm{R} 12$ & 454 & Total assets of business (in thousands) \\
\hline P2 & 1,077 & $\begin{array}{l}\text { Total sales of business for fiscal year ending } 1998 \\
\text { (in thousands) }\end{array}$ \\
\hline profit & 139 & $\begin{array}{l}\text { Business' total profit or loss for the fiscal year } \\
\text { ending } 1998 \text { (in thousands) }\end{array}$ \\
\hline minconwho & 0.2 & $\begin{array}{l}\text { Business' industry is mining, construction, or } \\
\text { wholesale, indicated by } 10<=\operatorname{sic} 2 r<=19,50 \text {, or } 51\end{array}$ \\
\hline retail & 0.18 & $\begin{array}{l}\text { Business' industry is retail, indicated by } \\
52<=\operatorname{sic} 2 r<=59\end{array}$ \\
\hline services & 0.43 & $\begin{array}{l}\text { Business' industry is services, indicated by } \\
70<=\text { sic } 2 \mathrm{r}<=89\end{array}$ \\
\hline trainsoth & 0.11 & $\begin{array}{l}\text { Business' industry is transportation, insurance, } \\
\text { or other, indicated by } 40<=\operatorname{sic} 2 r<=49 \text {, } \\
60<=\operatorname{sic} 2 r<=69 \text {, or } 99\end{array}$ \\
\hline manuf & 0.09 & $\begin{array}{l}\text { Business' industry is manufacturing, indicated by } \\
20<=\operatorname{sic} 2 r<=39\end{array}$ \\
\hline ccorp & 0.2 & $\begin{array}{l}\text { Business' organizational form is c-corporation, } \\
\text { indicated by } b 3=4,6 \text {, or } 8\end{array}$ \\
\hline scorp & 0.23 & $\begin{array}{l}\text { Business' organizational form is s-corporation, } \\
\text { indicated by b3 = } 5\end{array}$ \\
\hline partner & 0.06 & $\begin{array}{l}\text { Business' organizational form is partnership, } \\
\text { indicated by } b 3=2,3 \text {, or } 7\end{array}$ \\
\hline sole & 0.5 & $\begin{array}{l}\text { Business' organizational form is sole } \\
\text { proprietorship, indicated by b3 }=1 \text { or } 9\end{array}$ \\
\hline c_fage & 13.86 & Age of firm in years \\
\hline$\overline{D 1}$ & 1.4 & Number of sites where the firm has offices \\
\hline msa & 0.78 & $\begin{array}{l}\text { MSA indicator }=1 \text { if in Metropolitan Statistical } \\
\text { Area }\end{array}$ \\
\hline college & 0.49 & $\begin{array}{l}\text { Business owner's possession of a college degree, } \\
\text { indicated by } c \text { educ }=6 \text { or } 7\end{array}$ \\
\hline c_exp & 18.75 & $\begin{array}{l}\text { Amount of business experience the principal owner } \\
\text { of the business has had }\end{array}$ \\
\hline c_oage & 50.54 & Age of the principal owner of the business \\
\hline loan_tc_cccredit & 0.67 & $\begin{array}{l}\text { Did the business have a loan or borrow on trade } \\
\text { credit or credit card, indicated by loan }=1 \text {, or } \\
\mathrm{f} 3=1 \text {, or } f 6=1 \text {, or } L 6=1\end{array}$ \\
\hline loan & 0.55 & $\begin{array}{l}\text { Did the business have any loan, indicated by } \mathrm{f} 7=1 \text {, } \\
\text { or } \mathrm{f} 16=1 \text {, or } \mathrm{f} 20=1 \text {, or } \mathrm{f} 27=1 \text {, or } \mathrm{f} 42=1 \text {, } \\
\text { or } \mathrm{f} 33=1\end{array}$ \\
\hline capls & 0.11 & $\begin{array}{l}\text { Did the business have a capital lease, indicated by } \\
\mathrm{f} 16=1\end{array}$ \\
\hline crdline & 0.29 & $\begin{array}{l}\text { Did the business have any credit lines, indicated } \\
\text { by } f 7=1\end{array}$ \\
\hline eqploan & 0.1 & $\begin{array}{l}\text { Did the business have any equipment loans, } \\
\text { indicated by } \mathrm{f} 33=1\end{array}$ \\
\hline mortg & 0.13 & Did the business have any mortgages, indicated by \\
\hline
\end{tabular}




\begin{tabular}{|c|c|}
\hline mvloan & 0.21 \\
\hline othloan & 0.1 \\
\hline ccborrow & 0.15 \\
\hline buscc & 0.35 \\
\hline perscc & 0.46 \\
\hline tcborrow & 0.27 \\
\hline tradecr & 0.63 \\
\hline checking & 0.94 \\
\hline savings & 0.23 \\
\hline ownloan & 0.14 \\
\hline anyinst & 0.97 \\
\hline primebank & 0.84 \\
\hline plength & 97.33 \\
\hline db_perct & 51.66 \\
\hline dentrade & 0.05 \\
\hline bankrupt & 0.02 \\
\hline delpers & 0.07 \\
\hline delbus & 0.08 \\
\hline judge & 0.03 \\
\hline home & 0.89 \\
\hline loanapp & 0.23 \\
\hline multloanapp & 0.12 \\
\hline approved & 0.76 \\
\hline feared & \\
\hline
\end{tabular}

$\mathrm{f} 20=1$

Did the business have any motor vehicle loans, indicated by $\mathrm{f} 27=1$

Did the business have any other loans, indicated by $\mathrm{f} 42=1$

Did the business borrow on credit cards, indicated by $\mathrm{f} 3=1$, or $\mathrm{f} 6=1$

Did the owner use a business credit card, indicated by $f 4=1$

Did the owner use a personal credit card for business purposes, indicated by $\mathrm{f} 1=1$

Did the business borrow on trade credit, indicated by $L 6=1$

Did the business have trade credit, indicated by $\mathrm{L} 1=1$

Did the business have any checking accounts, indicated by $\mathrm{e} 1=1$

Did the business have any savings accounts, indicated by e $4=1$

Did the owner loan money to the business, indicated by $\mathrm{f} 39=1$

Did the business have at least 1 institution, indicated by numser $=1$

Was the business' primary institution a commercial bank, indicated by ptype $=1$

Length of relationship with primary institution in months

Dun \& Bradstreet Credit Score - Higher percentage indicates lower risk

Was the business denied trade credit, indicated by $\mathrm{L} 13=1$

Did the business, owner, or both declare bankruptcy within the past 7 years, indicated by $u 1=1$

Was the business owner delinquent on personal obligations within the past 3 years, indicated by $\mathrm{u} 2=4$

Was the business owner delinquent on business obligations within the past 3 years, indicated by u3 $=4$

Were there any judgments against the business owner during the past 3 years, indicated by $u 4=1$

Did the business owner own their own home, indicated by $u \_$home $=1$

Did the business apply for any loans, indicated by mrlr1>=1

Did the business apply for multiple loans, indicated by mrlr $1>1$

Was the business always approved for loans, indicated by $\mathrm{mrlr} 4=1$

Did the business owner not apply for loans fearing denial, indicated by $\mathrm{mrl} 31=1$ 
approved original

interest rate

9.22

approved points

to close

0.17

approved total

cost of

obtaining loan
What was the approved original interest rate of the particular loan, mrl20

How many percentage points did the business have to pay to close the loan/line of credit, $\mathrm{mrl} 21$

1,607
What was the total dollar amount of fees associated with obtaining the loan/line of credit (in thousands), mrl22 


\section{Appendix B}

Table B.1

SSBF 1998 Weighted Means - Firm \& Owner Characteristics

\section{Variables}

Total Employment

Assets

Sales

Profit

Mining, Construction, Wholesale

Retail

Service

Transportation, Insurance, Other

Manufacturing

Firm Age

C-Corporation

S-Corporation

Partnership

Sole Proprietorship

Number of Sites

MSA

College Graduate

Years of Experience of Owner

Age of Owner

Number in Sample

*Statistically Significant ( $>1.96)$

\begin{tabular}{|c|c|c|c|c|c|c|c|c|c|}
\hline \multicolumn{2}{|c|}{ All } & \multicolumn{2}{|c|}{95 Sales } & \multicolumn{2}{|c|}{$<5$ Emp } & \multicolumn{2}{|c|}{ Retail } & \multicolumn{2}{|c|}{ Services } \\
\hline Male & Female & Male & Female & Male & Female & Male & Female & Male & Female \\
\hline * 9.88 & 6.25 & 6.96 & 5.68 & 2.40 & 2.27 & * 10.94 & 7.34 & * 8.04 & 4.45 \\
\hline * $\$ 524,447$ & $\$ 241,809$ & * $\$ 289,983$ & $\$ 164,742$ & * $\$ 152,862$ & $\$ 92,918$ & * \$493,048 & $\$ 186,031$ & * $\$ 269,443$ & $\$ 81,223$ \\
\hline * $\$ 1,239,138$ & $\$ 585,145$ & * $\$ 500,839$ & $\$ 275,499$ & * $\$ 262,288$ & $\$ 122,540$ & * $\$ 1,482,325$ & $\$ 503,285$ & * $\$ 610,057$ & $\$ 174,247$ \\
\hline * \$156,629 & $\$ 87,328$ & $\$ 64,877$ & $\$ 58,299$ & $\$ 56,168$ & $\$ 31,337$ & $\$ 177,104$ & $\$ 55,651$ & * $\$ 88,799$ & $\$ 37,853$ \\
\hline * $23.43 \%$ & $9.47 \%$ & * $22.81 \%$ & $9.16 \%$ & * $21.74 \%$ & $8.75 \%$ & & & & \\
\hline * $16.39 \%$ & $23.29 \%$ & * $16.33 \%$ & $23.34 \%$ & * $14.02 \%$ & $21.47 \%$ & & & & \\
\hline * $40.32 \%$ & $49.15 \%$ & * $41.33 \%$ & $49.61 \%$ & * $45.88 \%$ & $52.37 \%$ & & & & \\
\hline $10.87 \%$ & $10.35 \%$ & $10.98 \%$ & $10.19 \%$ & $10.42 \%$ & $10.09 \%$ & & & & \\
\hline $8.99 \%$ & $7.74 \%$ & $8.55 \%$ & $7.71 \%$ & $7.93 \%$ & $7.32 \%$ & & & & \\
\hline * 14.66 & 11.44 & * 14.30 & 11.37 & * 13.80 & 10.69 & * 14.06 & 10.66 & * 14.06 & 11.41 \\
\hline * $20.94 \%$ & $16.97 \%$ & $19.68 \%$ & $16.51 \%$ & $12.86 \%$ & $11.08 \%$ & $19.60 \%$ & $14.64 \%$ & * $18.40 \%$ & $11.48 \%$ \\
\hline * $24.62 \%$ & $19.95 \%$ & * $23.98 \%$ & $19.72 \%$ & $17.99 \%$ & $14.91 \%$ & $22.52 \%$ & $21.78 \%$ & * $21.82 \%$ & $15.87 \%$ \\
\hline $6.30 \%$ & $6.15 \%$ & $6.34 \%$ & $6.22 \%$ & $5.80 \%$ & $6.21 \%$ & $5.55 \%$ & $7.38 \%$ & $5.51 \%$ & $4.33 \%$ \\
\hline * $48.14 \%$ & $56.93 \%$ & * $50.00 \%$ & $57.56 \%$ & $63.34 \%$ & $67.79 \%$ & $52.34 \%$ & $56.20 \%$ & * $54.26 \%$ & $68.32 \%$ \\
\hline 1.49 & 1.12 & 1.43 & 1.09 & 1.46 & 1.08 & 2.76 & 1.13 & * 1.24 & 1.10 \\
\hline $77.79 \%$ & $79.47 \%$ & $77.36 \%$ & $79.41 \%$ & * $76.60 \%$ & $81.83 \%$ & $67.52 \%$ & $70.82 \%$ & $82.64 \%$ & $81.24 \%$ \\
\hline * $50.48 \%$ & $42.59 \%$ & * $49.93 \%$ & $42.28 \%$ & * $48.54 \%$ & $38.53 \%$ & $36.44 \%$ & $41.43 \%$ & * $62.33 \%$ & $44.77 \%$ \\
\hline * 19.98 & 15.03 & * 19.74 & 14.95 & * 19.22 & 14.10 & * 20.32 & 15.17 & * 19.29 & 14.69 \\
\hline * 50.96 & 49.27 & * 50.79 & 49.22 & * 50.90 & 49.02 & 50.48 & 49.45 & * 51.15 & 48.71 \\
\hline 2087 & 605 & 1717 & 575 & 990 & 390 & 368 & 144 & 781 & 289 \\
\hline
\end{tabular}


Table B.2

SSBF 1998 Weighted Means - Financing Patterns

\section{Variables}

Have Outstanding Loan

Capital Lease

Credit Line

Equipment Loan

Mortgage

Motor Vehicle Loan

Other Loan

Have Loan or Borrow on Credit Cards or Trade Credit

Business Credit Card

Personal Credit Card for Business Purposes

Borrowed on Credit Card

Used trade credit

Borrowed on Trade Credit

Checking Account

Savings Account

Loan from Owner(s)

Primary Institution is a Bank

Primary Institution is a Depository Institution

Primary Institution is a Financial Institution not Bank

Primary Institution is Another Type of Institution

Length of Relationship with Primary Institution in Months

Used Any Institution

Number in Sample

*Statistically Significant ( $>1.96)$
All

\begin{tabular}{l}
\hline Male \\
* $58.34 \%$ \\
* $11.62 \%$ \\
* $31.84 \%$ \\
* $11.78 \%$ \\
$13.01 \%$ \\
* $23.35 \%$ \\
$9.67 \%$ \\
* $68.98 \%$ \\
* $36.15 \%$ \\
$45.96 \%$ \\
* $13.64 \%$ \\
* $66.41 \%$ \\
$27.97 \%$ \\
* $95.60 \%$ \\
$22.46 \%$ \\
$14.25 \%$ \\
$84.90 \%$ \\
$9.77 \%$ \\
$3.61 \%$ \\
$1.73 \%$ \\
* 100 \\
* $98.00 \%$
\end{tabular}

2087
95 Sales

Female Male Female

$46.50 \%$

$7.73 \%$

$18.78 \%$

$5.32 \%$

$13.12 \%$

$13.33 \%$

$9.92 \%$

$62.07 \%$

$29.95 \%$

$47.36 \%$

$19.97 \%$

$53.59 \%$

$24.12 \%$

$90.51 \%$

$24.55 \%$

$13.42 \%$

$82.15 \%$

$12.28 \%$

$3.72 \%$

$1.85 \%$

88

$92.69 \%$

* $57.15 \% \quad 45.96 \%$

- $11.00 \% \quad 7.66 \%$

*29.98\% $18.07 \%$

* $11.24 \% \quad 5.22 \%$

$12.66 \% \quad 13.15 \%$

* $23.04 \% \quad 13.19 \%$

$9.31 \% \quad 9.86 \%$

* $68.18 \% \quad 61.65 \%$

* $34.83 \% \quad 29.73 \%$

$46.95 \%$
$* 14.16 \%$

$\begin{array}{r}4.16 \% \\ * 65.69 \% \\ \hline\end{array}$

$27.44 \%$

$\begin{array}{r}27.44 \% \\ * 95.42 \% \\ \hline\end{array}$

$24.05 \%$
$90.41 \%$

$84.63 \% \quad 81.96 \%$

$10.05 \% \quad 12.40 \%$

$3.55 \% \quad 3.77 \%$

$1.76 \%$

* 99

$1.87 \%$

* $97.92 \%$
$13.64 \% \quad 13.08 \%$

\section{Male

Male Female \\ * $47.86 \% \quad 39.09 \%$}

$4.35 \% \quad 4.29 \%$

* $22.13 \% \quad 13.63 \%$

* $8.00 \%$

$10.44 \%$

$3.06 \%$

$18.65 \% \quad 11.92 \%$

$7.71 \% \quad 8.86 \%$

$61.55 \% \quad 57.29 \%$

$27.99 \% \quad 24.53 \%$

$46.96 \% \quad 48.17 \%$

* $15.18 \% \quad 20.15 \%$

* $59.26 \% \quad 48.25 \%$

$23.38 \% \quad 21.98 \%$

* $93.56 \% \quad 87.93 \%$

$18.66 \% \quad 20.96 \%$

$9.21 \% \quad 10.01 \%$

$83.02 \% \quad 81.17 \%$

$11.92 \% \quad 14.28 \%$

$3.50 \% \quad 3.31 \%$

$1.57 \%$

* 97

$1.25 \%$

+97.09\% $90.83 \%$

1717

575

990

390
Retail

Male

$56.78 \%$

$7.79 \%$

$26.52 \%$

$8.01 \%$

$19.08 \%$

$8.35 \%$

$67.80 \%$

$31.43 \%$

* $36.64 \%$
* $13.35 \%$

$63.81 \%$

* $24.70 \%$

$96.29 \%$

$18.47 \%$

$12.91 \%$

$90.02 \%$

$4.67 \%$

$3.35 \%$

* $1.97 \%$

$98.37 \%$

368
Female $\frac{\text { Services }}{\text { Male }}$

$49.08 \% \quad * 52.43 \% \quad 39.94 \%$

$5.29 \% \quad * 12.65 \% \quad 8.10 \%$

$23.00 \% \quad * 28.22 \% \quad 13.71 \%$

$7.23 \% \quad * 11.25 \% \quad 4.36 \%$

$14.35 \% \quad 10.68 \% \quad 12.66 \%$

$15.09 \% \quad * 19.15 \% \quad 8.25 \%$

$12.41 \% \quad 7.99 \% \quad 8.06 \%$

$69.20 \% \quad * 66.82 \% \quad 54.70 \%$

$32.68 \% \quad 33.41 \% \quad 28.53 \%$

$49.36 \% \quad 52.14 \% \quad 48.62 \%$

$25.47 \% \quad 17.09 \% \quad 18.06 \%$

$70.61 \% \quad * 61.89 \% \quad 44.73 \%$

$36.59 \% \quad * 27.67 \% \quad 16.68 \%$

$96.04 \% \quad * 94.32 \% \quad 87.21 \%$

$21.97 \% \quad 23.71 \% \quad 25.78 \%$

$14.86 \% \quad 11.36 \% \quad 8.91 \%$

$89.61 \% \quad * 81.97 \% \quad 74.31 \%$

$6.61 \% \quad * 12.22 \% \quad 18.86 \%$

$1.84 \% \quad 4.02 \% \quad 3.95 \%$

$1.94 \% \quad 1.79 \% \quad 2.87 \%$

$75 \quad 92 \quad 91$

$96.96 \% \quad * 97.90 \% \quad 90.31 \%$

$144 \quad 781 \quad 289$ 
Table B.3

SSBF 1998 Weighted Means - Credit History

\section{Variables}

Dun \& Bradstreet Credit Score

Denied trade credit

Bankruptcy by Firm in Last 7 Years

Delinquency on Personal Obligations

Delinquency on Business Obligations

Judgment Against Owner

Owner Owns Home

Loan Application

Multiple Loan Applications

oan Application(s) Always Approved

Didn't Apply Fearing Denial

Approved Original Interest Rate

Approved Points to Close

Approved Total Cost of Obtaining Loan

Number in Sample

*Statistically Significant ( $t>1.96)$

\begin{tabular}{|c|c|c|c|c|c|c|c|c|c|}
\hline \multicolumn{2}{|c|}{ All } & \multicolumn{2}{|c|}{95 Sales } & \multicolumn{2}{|c|}{$<5$ Emp } & \multicolumn{2}{|c|}{ Retail } & \multicolumn{2}{|c|}{ Services } \\
\hline Male & Female & Male & Female & Male & Female & Male & Female & Male & Female \\
\hline * 52.64 & 48.70 & * 52.29 & 48.51 & * 51.76 & 47.93 & 49.51 & 47.89 & * 52.34 & 48.41 \\
\hline $4.89 \%$ & $5.51 \%$ & $4.98 \%$ & $5.55 \%$ & $4.35 \%$ & $5.65 \%$ & $3.95 \%$ & $8.50 \%$ & $4.37 \%$ & $4.09 \%$ \\
\hline $2.09 \%$ & $2.03 \%$ & $2.17 \%$ & $2.06 \%$ & $2.45 \%$ & $2.22 \%$ & $1.18 \%$ & $0.80 \%$ & $3.20 \%$ & $3.08 \%$ \\
\hline $6.55 \%$ & $6.50 \%$ & $6.79 \%$ & $6.57 \%$ & $6.85 \%$ & $7.38 \%$ & $3.32 \%$ & $7.44 \%$ & $7.95 \%$ & $5.45 \%$ \\
\hline $8.08 \%$ & $7.06 \%$ & $8.08 \%$ & $7.12 \%$ & $5.90 \%$ & $6.31 \%$ & $7.86 \%$ & $11.00 \%$ & $7.54 \%$ & $4.96 \%$ \\
\hline $3.57 \%$ & $2.77 \%$ & $3.64 \%$ & $2.80 \%$ & $3.93 \%$ & $3.36 \%$ & $2.23 \%$ & $3.32 \%$ & $3.89 \%$ & $2.10 \%$ \\
\hline $89.44 \%$ & $88.11 \%$ & $89.05 \%$ & $88.08 \%$ & $87.69 \%$ & $87.71 \%$ & $87.06 \%$ & $85.71 \%$ & $86.88 \%$ & $88.08 \%$ \\
\hline * $24.07 \%$ & $19.22 \%$ & * $23.76 \%$ & $18.83 \%$ & * $20.37 \%$ & $15.29 \%$ & $21.76 \%$ & $25.23 \%$ & * $22.82 \%$ & $13.36 \%$ \\
\hline * $13.37 \%$ & $8.12 \%$ & * $13.22 \%$ & $8.10 \%$ & * $10.36 \%$ & $6.62 \%$ & $7.35 \%$ & $7.92 \%$ & * $12.97 \%$ & $5.34 \%$ \\
\hline $76.11 \%$ & $76.55 \%$ & $75.33 \%$ & $76.16 \%$ & $76.06 \%$ & $69.01 \%$ & $79.46 \%$ & $79.35 \%$ & $70.40 \%$ & $73.68 \%$ \\
\hline $20.16 \%$ & $24.19 \%$ & $20.78 \%$ & $24.43 \%$ & $21.31 \%$ & $25.67 \%$ & $19.32 \%$ & $28.41 \%$ & $20.40 \%$ & $19.30 \%$ \\
\hline $9.29 \%$ & $8.94 \%$ & $9.37 \%$ & $9.00 \%$ & $9.61 \%$ & $9.25 \%$ & $9.30 \%$ & $9.54 \%$ & $9.22 \%$ & $8.54 \%$ \\
\hline $16.67 \%$ & $16.40 \%$ & $16.45 \%$ & $16.99 \%$ & $10.24 \%$ & $7.85 \%$ & $24.00 \%$ & $15.41 \%$ & $9.48 \%$ & $4.91 \%$ \\
\hline$\$ 1,635$ & $\$ 1,493$ & $\$ 1,281$ & $\$ 1,343$ & $\$ 855$ & $\$ 531$ & $\$ 1,572$ & $\$ 561$ & $\$ 816$ & $\$ 777$ \\
\hline 2087 & 605 & 1717 & 575 & 990 & 390 & 368 & 144 & 781 & 289 \\
\hline
\end{tabular}

